\title{
Tissue pyridoxal phosphate concentration and pyridoxaminephosphate oxidase activity in riboflavin deficiency in rats and man
}

\author{
By AMBALE V. LAKSHMI AND M. S. BAMJI \\ National Institute of Nutrition, Indian Council of Medical Research, \\ Famai-Osmania, Hyderabad-500007, India \\ (Received 7 August 1973-Accepted 2 November 1973)
}

\begin{abstract}
I. Parenteral administration of pyridoxal $5^{\prime}$-phosphate (PALP) to riboflavin-deficient rats increased the non-FAD component of erythrocyte riboflavin.

2. Pyridoxaminephosphate oxidase $\left(E C C_{1} \cdot 4 \cdot 3 \cdot 5\right)$ activity in the livers of riboflavin-deficient animals was only I $5 \%$ of that of controls. PALP concentration in blood, liver and brain was not affected. Deficient animals had higher levels of pyridoxine in liver.

3. Human subjects with lesions of the mouth responded to treatment with either riboflavin or pyridoxine.

4. PALP concentration of human blood was not affected by administration of riboflavin but was markedly increased by pyridoxine.

5. Erythrocyte glutathione reductase activity $\left(E C C_{1} .6 .4 .2\right)$ in humans was increased and in vitro stimulation of the enzyme with FAD was decreased by treatment with riboflavin, but not by treatment with pyridoxine.
\end{abstract}

Formation of pyridoxal $5^{\prime}$-phosphate (PALP) in animal tissues is catalysed by the flavin enzyme pyridoxaminephosphate oxidase $(E C \mathrm{I} \cdot 4 \cdot 3 \cdot 5)$, which has FMN as cofactor (Wada \& Snell, 1961). Biochemical evidence of pyridoxine deficiency, as judged by increased excretion of urinary metabolites of tryptophan, has been reported in riboflavin-deficient rats (Mason, I953). In a clinical study, treatment with riboflavin reduced the excretion of tryptophan metabolites following cortisol administration (Rose \& McGinty, 1968). Nakahara, Watanabe, Morino \& Sakamoto ( 1961 ) have shown that riboflavin deficiency of 2 weeks duration in young rats results in a slight fall in pyridoxaminephosphate oxidase activity and PALP concentration of liver. All these findings indicate that riboflavin deficiency may interfere with the proper utilization of pyridoxine.

Lesions of the mouth, such as angular stomatitis and glossitis, have been shown in experimentally-induced riboflavin deficiency as well as in pyridoxine deficiency. Recent reports from our Institute show that this condition, which is quite commonly seen in India, responds clinically to treatment with either riboflavin or pyridoxine (Krishnaswamy, I97I; Iyengar, I973).

From the above-mentioned biochemical inter-relationship between riboflavin and pyridoxine, we postulated that the biochemical basis for oral lesions could be a cellular deficiency of PALP either due to dietary insufficiency of pyridoxine or conditioned by inefficient conversion of dietary pyridoxine to its coenzyme form PALP, as a result of riboflavin deficiency (Bamji, I97I). Some reports, however, contradict this. Chatterjee, Jamdar \& Ghosh (1966) have shown that riboflavin deficiency in rats 
increases PALP concentration in liver. Higher concentrations of aminotransferases, which are PALP-dependent enzymes, have been observed in tissues of riboflavindeficient rats and humans (Chatterjee et al. 1966; Krishnaswamy, 1971).

The object of this investigation was to study further the pyridoxaminephosphate oxidase-dependent inter-relationship between riboflavin and pyridoxine, and to assess its implications in the aetiopathology of lesions of the mouth that respond to both riboflavin and pyridoxine.

\section{EXPERIMENTAL}

Expt $\mathrm{I}$. Effect of parenteral administration of PALP on erythrocyte riboflavin concentration in riboflavin-deficient rats. It has been reported that both pyridoxal and PALP can enter the erythrocyte (Suzue \& Tachibana, I 970 ). Anderson, Fulford-Jones, Child, Beard \& Bateman (1971) have shown that pyridoxal can cross the erythrocyte membrane even better than pyridoxine. Therefore, parenteral administration of PALP should be able to provide cellular coenzyme without the help of the FMN-dependent step.

An experiment was conducted to see if parenterally administered PALP would modify tissue riboflavin concentration and erythrocyte glutathione reductase (EGR) $(E C$ I .6.4.2) activity.

Sixteen weanling albino rats of both sexes were given for $50 \mathrm{~d}$ a riboflavin- and pyridoxine-deficient diet formed by omitting those vitamins from the diet described by Bamji \& Sharada (1972). During this period eight rats received daily injections of I00 $\mu \mathrm{g}$ pyridoxine hydrochloride, and the other eight animals received equimolar amounts of PALP (120 $\mu \mathrm{g}$ ) in the same way. The animals were killed and their tissues examined for erythrocyte riboflavin and EGR, and liver riboflavin and PALP.

Expt 2. Effects of riboflavin deficiency on pyridoxaminephosphate oxidase activity and $P A L P$ concentrations in rats. The control diet for this experiment contained $8 \mathrm{mg}$ riboflavin/kg and was the same as that described by Bamji \& Sharada (I972), except that the concentration of pyridoxine was decreased from $5 \mathrm{mg} / \mathrm{kg}$ to $2.5 \mathrm{mg} / \mathrm{kg}$. The riboflavin-deficient diet was prepared by omitting riboflavin from the control diet. Twenty-four weanling albino rats of both sexes were divided into three groups to receive the control diet ad lib. or the riboflavin-deficient diet ad lib. or the control diet in amounts equal to the previous day's intake by the deficient group $(5.45 \pm$ $0.39 \mathrm{~g} /$ rat per d). The rats were killed by cervical dislocation on day $5^{\circ}$ and the tissues examined for liver pyridoxine concentration, liver pyridoxaminephosphate oxidase activity and PALP concentration in whole blood, liver and brain.

Expts 3 and 4. Human study. Adult subjects of both sexes with and without biochemical (EGR test) and clinical (oral lesions) evidence of riboflavin deficiency were used for this study. The subjects did not have evidence of any other deficiency or disease and had not received any drugs or vitamins. All the subjects with oral lesions and four subjects without lesions were from a low-income group and had a dietary history compatible with riboflavin and pyridoxine deficiency. Samples of blood were always taken before breakfast. Thirteen subjects received orally to $\mathrm{mg}$ riboflavin/d for a period of ro d (Expt 3 ) and their blood was examined (before and after treatment) 
Table I. Expt 1. Effects of parenteral administration of pyridoxal 5'-phosphate (PALP) or pyridoxine on erythrocyte riboflavin and glutathione reductase (EGR) and liver riboflavin, and PALP in weanling rats given a diet deficient in riboflavin and pyridoxine for $5 \circ d$

(Mean values with their standard errors)

\begin{tabular}{|c|c|c|c|c|c|}
\hline $\begin{array}{l}\text { Daily } \\
\text { injections }\end{array}$ & $\begin{array}{l}\text { No. of } \\
\text { rats }\end{array}$ & EGR† & $\begin{array}{c}\text { Erythrocyte } \\
\text { riboflavin } \\
\text { (ng/mi) }\end{array}$ & $\begin{array}{l}\text { Liver } \\
\text { riboflavin } \\
(\mu \mathrm{g} / \mathrm{g})\end{array}$ & $\begin{array}{l}\text { Liver } \\
\text { PALP } \\
(\mu \mathrm{g} / g)\end{array}$ \\
\hline Pyridoxine $100 \mu \mathrm{g}$ & 8 & $0.76 \pm 0.10$ & $27 \cdot 80 \pm 2 \cdot 90$ & $9.60 \pm 0.58$ & $6.09 \pm 0.97$ \\
\hline $\begin{array}{l}\text { Pyridoxal } 5^{\prime}- \\
\text { phosphate } 120 \mu \mathrm{g}\end{array}$ & 8 & $0.76 \pm 0.14$ & $42 \cdot 10 \pm 4 \cdot 24^{*}$ & $10 \cdot 31 \pm I \cdot 22$ & $7.15 \pm 0.67$ \\
\hline
\end{tabular}

for erythrocyte riboflavin, EGR and whole blood PALP. Four other subjects all with clinical and biochemical evidence of riboflavin deficiency received orally $20 \mathrm{mg}$ pyridoxine/d for a period of ro d and their blood was similarly examined (Expt 4).

Analysis of tissues. The following assays were done by methods described before: erythrocyte riboflavin (Sharada \& Bamji, I972), erythrocyte EGR and percentage stimulation of EGR with FAD (Bamji, I969), liver riboflavin (Bamji \& Sharada, I972), liver pyridoxine (Strobeker \& Henning, 1965), and liver pyridoxaminephosphate oxidase (Nakahara, Morino, Morisue \& Sakamoto, I96I). PALP content of liver and brain was measured by using apotryptophanase from Escherichia coli (Storvick, Benson, Edwards \& Woodring, I965). Blood PALP was assayed by the tyrosine decarboxylase ( $E C_{4}$. I. I.25) method (Sundaresan \& Coursin, I 970). The enzyme obtained from Worthington Biochemical Corporation (PO Box 650, Freehold, New Jersey $077^{28}$, USA) was used without further purification. Rat blood was diluted with ro vol. water and assayed without extraction. Human blood was extracted with perchloric acid as follows, before being assayed: $2.5 \mathrm{ml}$ blood was extracted with I $\mathrm{ml} 50 \%(\mathrm{v} / \mathrm{v})$ perchloric acid. The precipitate was washed with I $\mathrm{ml} 0.4 \mathrm{M}$-perchloric acid and the combined supernatant fraction adjusted to $\mathrm{pH} 5.5$ (P. R. Sundaresan, personal communication).

\section{RESULTS}

Expt I. Riboflavin-deficient rats which received PALP rather than pyridoxine showed a $50 \%$ increase in erythrocyte-riboflavin concentration without a corresponding change in EGR activity (Table $\mathbf{I}$ ).

Expt 2. Riboflavin deficiency led to a sharp fall in pyridoxaminephosphate oxidase activity of the liver, but did not modify the PALP concentrations in tissues such as blood, brain and liver. The total pyridoxine content of the liver was higher in deficient animals than in pair-fed controls (Table 2).

Expts 3 and 4. The results of Expt 3, given in Table 3, show that there was no correlation between blood PALP concentrations and riboflavin status as judged by the EGR test. Initial EGR activity was lower and stimulation with FAD was higher 
Table 2. Expt 2. Effect of riboflavin deficiency on liver pyridoxaminephosphate oxidase, and pyridoxine and pyridoxal 5'-phosphate $(P A L P)$ in blood, liver and brain of weanling rats given a control or riboflavin-deficient diet for $50 d$

(Mean values with their standard errors)

No. of rats $\ldots$

Initial body-wt $(\mathrm{g})$

Food intake ( $\mathrm{g} /$ rat per $\mathrm{d})$

Final body-wt (g)

Liver:

wt $(\mathrm{g})$

pyridoxine $(\mu \mathrm{g} / \mathrm{g})$

PALP $(\mu \mathrm{g} / \mathrm{g})$

Pyridoxaminephosphate oxidasef

Blood PALP (ng/ml)

Brain :

$\mathrm{Wt}(\mathrm{g})$

PALP $(\mu g / g)$
Ad lib. controls $\nmid$

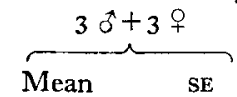

$46 \cdot 3 \circ$

10.84

$153 \cdot 30$

7.07

$6 \cdot 10$

$4 \cdot 83$

165.50

114.00

$\mathrm{r} \cdot 46$

0.95

$$
3.62
$$$$
0.43
$$

I2: 10

0.06

0.13
Pair-fed controls $\dagger$

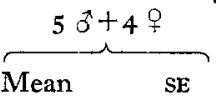$$
\text { I } 5 \cdot 23 * *
$$

$46 \cdot 50$

$5 \cdot 45$

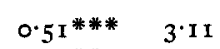

$0.12 * * \quad 4.52$

$0.64 \quad 4.44$

$4 \cdot 44$
$149 \cdot 20$

$10 \cdot 87^{* * *} \quad 66.40$

I. 54

$0 \cdot 39$

$2 \cdot 38$

0.07

0.62

0.48

$8 \cdot 53$
Riboflavin-deficient $\dagger$

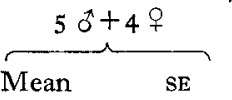

$46 \cdot 60 \quad I \cdot 94$

$5.45 \quad 0.39$

$59 \cdot 30$

$4 \cdot 38 * *$

$2.77 \quad 0.18$

$6.45 \quad 0.45^{* *}$

$4.27 \quad 0.47$

$27 \cdot 52 \quad 4 \cdot 35^{* *}$

10.10 $\quad 83.40 \quad 6.24$

$\begin{array}{lll}0.06 & \mathbf{1} 29 & 0.008\end{array}$

$\begin{array}{lll}0.11 & 0.99 & 0.21\end{array}$

Significantly different from pair-fed control value: ** $P<0.01$; *** $P<0.001$.

$\dagger$ For details of diets, see p. 250.

$\ddagger$ PALP formed from pyridoxaminephosphate $(\mathrm{nmol}) / \mathrm{g}$ liver per $30 \mathrm{~min}$.

in subjects with oral lesions than in those without oral lesions. Blood PALP fell after riboflavin treatment in three out of five subjects with symptoms and in five out of eight subjects without symptoms. EGR activity increased markedly, with simultaneous decrease in stimulation of the enzyme with FAD, in all the subjects after treatment. Subjects with lesions of the mouth responded clinically to treatment with riboflavin.

Results of Expt 4 (Table 4 ) show that whole blood PALP concentration of the four subjects increased markedly after treatment with pyridoxine and they also improved clinically. Subject no. 4 had failed to respond to treatment with riboflavin but showed complete recovery with pyridoxine. However, in subject nos I, 2 and 3 some residual lesions were still evident after $10 \mathrm{~d}$ of treatment with pyridoxine, EGR activity was not affected by administration of pyridoxine.

\section{DISCUSSION}

The results obtained in Expt $\mathrm{r}$ (Table $\mathrm{I}$ ) suggest that parenteral administration of PALP to riboflavin-deficient animals can spare the non-FAD component of erythrocyte riboflavin. In the liver, a similar effect might have been masked by the higher concentrations of riboflavin in that tissue and by the large variety of flavoproteins.

The fall in pyridoxaminephosphate oxidase activity of riboflavin-deficient rats observed in Expt 2 (Table 2) was greater than that observed by Nakahara, Watanabe et al. (I96I) and was probably due to the longer duration of deficiency. Yet, contrary 
Table 3. Expt 3. Effects of treatment with riboflavin (10 $\mathrm{mg} / \mathrm{d}$ for $\mathrm{10} d$ ) on blood pyridoxal 5 '-phosphate (PALP), erythrocyte glutathione reductase (EGR) and riboflavin in human subjects

\begin{tabular}{|c|c|c|c|c|c|c|}
\hline $\begin{array}{l}\text { Subjects } \\
\text { no. }\end{array}$ & $\begin{array}{l}\text { Clinical } \\
\text { signs of } \\
\text { angular } \\
\text { stomatitis } \\
\text { and } \\
\text { glossitis }\end{array}$ & & $\begin{array}{l}\text { Blood PALP } \\
(\mathrm{ng} / \mathrm{ml})\end{array}$ & EGR† & $\begin{array}{c}\text { Stimulation of } \\
\text { EGR by FAD } \\
(\%)\end{array}$ & $\begin{array}{c}\text { Erythrocyte } \\
\text { riboflavin } \\
(\mu \mathrm{g} / \mathrm{ml})\end{array}$ \\
\hline I & + & $\begin{array}{l}\mathrm{BT} \\
\mathrm{AT}\end{array}$ & $\begin{array}{l}8 \cdot 26 \\
6 \cdot 09\end{array}$ & $\begin{array}{l}4 \cdot 85 \\
6 \cdot 85\end{array}$ & $\begin{array}{r}123 \cdot 2 \\
21 \cdot 2\end{array}$ & $\begin{array}{l}0.22 \\
0.25\end{array}$ \\
\hline 2 & + & $\begin{array}{l}\mathrm{BT} \\
\mathrm{AT}\end{array}$ & $\begin{array}{l}9.03 \\
7 \cdot 51\end{array}$ & $\begin{array}{l}1 \cdot 90 \\
5 \cdot 10\end{array}$ & $\begin{array}{r}130.1 \\
20.2\end{array}$ & $\begin{array}{l}0.18 \\
0.28\end{array}$ \\
\hline 3 & + & $\begin{array}{l}\text { BT } \\
\text { A'T }\end{array}$ & $\begin{array}{l}5 \cdot 51 \\
I \cdot 39\end{array}$ & $\begin{array}{l}3 \cdot 50 \\
7 \cdot 10\end{array}$ & $\begin{array}{l}97 \cdot 3 \\
12 \cdot 2\end{array}$ & $\begin{array}{l}0.16 \\
0.30\end{array}$ \\
\hline 4 & + & $\begin{array}{l}\mathrm{BT} \\
\mathrm{AT}\end{array}$ & $\begin{array}{l}5 \cdot 93 \\
8 \cdot 00\end{array}$ & $\begin{array}{l}3.50 \\
8.90\end{array}$ & $\begin{array}{r}100.0 \\
23.5\end{array}$ & $\begin{array}{l}0.20 \\
0.32\end{array}$ \\
\hline 5 & + & $\begin{array}{l}\mathrm{BT} \\
\mathrm{AT}\end{array}$ & $\begin{array}{l}3 \cdot 20 \\
5 \cdot 84\end{array}$ & $\begin{array}{r}6.20 \\
13.40\end{array}$ & $\begin{array}{c}82 \cdot 0 \\
--\end{array}$ & - \\
\hline 6 & - & $\begin{array}{l}\mathrm{BT} \\
\mathrm{AT}\end{array}$ & $\begin{array}{l}5.06 \\
3.62\end{array}$ & $\begin{array}{r}6 \cdot 50 \\
15.10\end{array}$ & $\begin{array}{r}107.0 \\
34.0\end{array}$ & $\begin{array}{l}0.18 \\
0.33\end{array}$ \\
\hline 7 & - & $\begin{array}{l}\text { BT } \\
\text { AT }\end{array}$ & $\begin{array}{l}4 \cdot 04 \\
4 \cdot 38\end{array}$ & $\begin{array}{r}7 \cdot 35 \\
16 \cdot 50\end{array}$ & $\begin{array}{r}109 \cdot 7 \\
10.0\end{array}$ & $\begin{array}{l}0.22 \\
0.34\end{array}$ \\
\hline 8 & - & $\begin{array}{l}\text { B'T } \\
\text { AT }\end{array}$ & $\begin{array}{l}8 \cdot 26 \\
8 \cdot 31\end{array}$ & $\begin{array}{r}8 \cdot 70 \\
15 \cdot 10\end{array}$ & $\begin{array}{l}79.3 \\
33.0\end{array}$ & $\begin{array}{l}0.22 \\
0.32\end{array}$ \\
\hline 9 & - & $\begin{array}{l}\text { BT } \\
\text { AT }\end{array}$ & $\begin{array}{l}5.86 \\
6.87\end{array}$ & $\begin{array}{r}8.90 \\
15.10\end{array}$ & $\begin{array}{l}60.0 \\
23.0\end{array}$ & $\begin{array}{l}0.19 \\
0.22\end{array}$ \\
\hline 10 & - & $\begin{array}{l}\text { BT } \\
\text { AT }\end{array}$ & $\begin{array}{l}4 \cdot 18 \\
3 \cdot 43\end{array}$ & $\begin{array}{l}14.90 \\
15.60\end{array}$ & $\begin{array}{l}45^{\circ} \circ \\
25^{\circ} \circ\end{array}$ & $\begin{array}{l}0.23 \\
0.30\end{array}$ \\
\hline I I & - & $\begin{array}{l}\text { BT } \\
\text { AT }\end{array}$ & $\begin{array}{l}5 \cdot 16 \\
4 \cdot 43\end{array}$ & $\begin{array}{r}9.90 \\
14.90\end{array}$ & $\begin{array}{l}16 \cdot 1 \\
10 \cdot 0\end{array}$ & $\begin{array}{l}0.20 \\
0.30\end{array}$ \\
\hline 12 & - & $\begin{array}{l}\text { BT } \\
\text { AT }\end{array}$ & $\begin{array}{l}6.30 \\
5.74\end{array}$ & $\begin{array}{l}15 \cdot 10 \\
16 \cdot 10\end{array}$ & $\begin{array}{l}27 \cdot 0 \\
20 \cdot 0\end{array}$ & $\begin{array}{l}0.22 \\
0.28\end{array}$ \\
\hline$r_{3}$ & - & $\begin{array}{l}\text { BT } \\
\text { AT }\end{array}$ & $\begin{array}{l}4 \cdot 23 \\
2 \cdot 00\end{array}$ & $\begin{array}{l}13.00 \\
15.30\end{array}$ & $\begin{array}{r}20.0 \\
6.0\end{array}$ & $\begin{array}{l}0.20 \\
0.22\end{array}$ \\
\hline Mean $\pm S E$ & & $\begin{array}{l}\mathrm{BT} \\
\mathrm{AT}\end{array}$ & $\begin{array}{r}5.77 \\
\pm 0.49 \\
5.20 \\
\pm 0.61\end{array}$ & $\begin{array}{r}8 \cdot 02 \\
\pm 1 \cdot 19 \\
12.69 * \\
\pm 1 \cdot 13\end{array}$ & $\begin{array}{c}77 \cdot 4 \\
\pm 11 \cdot 15 \\
18 \cdot 30^{*} \\
\pm 2 \cdot 81\end{array}$ & $\begin{array}{c}0.20 \\
\pm 0.006 \\
0.28 * \\
\pm 0.01\end{array}$ \\
\hline
\end{tabular}

BT, before treatment with riboflavin; A'T, after treatment with riboflavin; + , clinical signs present; - , clinical signs absent.

Value significantly different from the corresponding value before treatment: $* P<0 \cdot 00$.

$\dagger \mathrm{mg}$ reduced glutathione formed $/ \mathrm{ml}$ erythrocytes per $15 \mathrm{~min}$.

to the experience of the Japanese workers, PALP concentration in tissues such as blood, liver and brain did not diminish in riboflavin-deficient rats. The contradictory findings of Nakahara, Watanabe et al. (1961), Chatterjee et al. (1966) and ourselves with regard to PALP concentrations in riboflavin deficiency are hard to explain.

The lack of correlation between riboflavin status and blood PALP in humans agrees with the results obtained in animal studies and fails to support our hypothesis that lesions of the mouth are due to cellular deficiency of PALP. 
Table 4. Expt 4. Effect of treatment with pyridoxine ( $20 \mathrm{mg} / \mathrm{d}$ for $\mathrm{10}$ d) on blood pyridoxal 5 -phosphate (PALP), erythrocyte glutathione reductase $(E G R)$ and riboflavin in human subjects with angular stomatitis and glossitis

\begin{tabular}{|c|c|c|c|c|c|c|c|c|}
\hline \multirow[t]{2}{*}{ Subject } & \multicolumn{2}{|c|}{$\begin{array}{l}\text { Blood PALP } \\
\text { (ng/mi) }\end{array}$} & \multicolumn{2}{|c|}{ EGR* } & \multicolumn{2}{|c|}{$\begin{array}{c}\text { Stimulation of EGR } \\
\text { by FAD }(\%)\end{array}$} & \multicolumn{2}{|c|}{$\begin{array}{c}\text { Riboflavin } \\
\text { ( } \mu \mathrm{g} / \mathrm{ml} \text { erythrocytes })\end{array}$} \\
\hline & $\mathrm{BT}$ & $\mathrm{AT}$ & BT & $\mathrm{AT}$ & $\mathrm{BT}^{\prime} \mathrm{T}$ & $\mathrm{AT}$ & $\mathrm{BT}$ & AT \\
\hline I & 6.80 & 19.84 & $7 \cdot I$ & $8 \cdot 75$ & $66 \cdot 3$ & 64.0 & 0.17 & 0.15 \\
\hline 2 & $5 \cdot 08$ & $23 \cdot 55$ & $6 \cdot 0$ & $7 \cdot 15$ & $177^{\circ} 0$ & 140.0 & 0.14 & 0.15 \\
\hline 3 & $5 \cdot \mathrm{OI}$ & $2 \mathrm{I} \cdot 00$ & $7 \cdot 3$ & $9 \cdot 75$ & $9 \mathrm{I} \cdot \mathrm{O}$ & 83.0 & 0.20 & 0.19 \\
\hline $4 \dagger$ & 5.79 & $22 \cdot 80$ & $9 \cdot 5$ & $8 \cdot 10$ & 10.0 & $20 \cdot 0$ & 0.30 & 0.28 \\
\hline Mean & 5.67 & $21 \cdot 79$ & $7 \cdot 47$ & $8 \cdot 43$ & 86.07 & 76.75 & 0.22 & 0.19 \\
\hline
\end{tabular}

$\mathrm{BT}$, before treatment with pyridoxine; AT, after treatment with pyridoxine.

* $\mathrm{mg}$ reduced glutathione formed $/ \mathrm{ml}$ erythrocytes per $15 \mathrm{~min}$.

$\uparrow$ Subject 4 was previously treated with riboflavin but did not respond clinically.

The clinical response to riboflavin or pyridoxine (Expts 3 and 4 ) observed in this study is consistent with the earlier reports from our Institute (Krishnaswamy, I97 I ; Iyengar, 1973). However, the results of Expt 4 show that the healing of oral lesions like angular stomatitis and glossitis is not necessarily associated with improvement in EGR activity.

The following possibilities need to be considered to explain the observations made in this investigation: $(a)$ the enzymatic lesion due to riboflavin deficiency, though severe, is still not a restraint on the cells' capacity to form PALP; $(b)$ although the FMN-dependent pathway is the physiologically important pathway for the formation of tissue PALP in normal rats and in animals with mild or early riboflavin deficiency, in severe deficiency an alternative FMN-independent pathway may come into operation. This would explain the conflicting reports of Nakahara, Watanabe et al. (1961), Chatterjee et al. (1966) and the present study; (c) in riboflavin-deficient animals, the utilization or breakdown of PALP may be slower. The rate of growth of deficient animals being slower than the pair-fed control animals, for the same intake of pyridoxine, the latter may have utilized more cellular PALP. The accumulation of pyridoxine in the livers of deficient animals observed in Expt 2 supports such an argument (Table 2); (d) PALP concentrations in tissues such as liver, brain and blood may not reflect the body pool of PALP, as most of the coenzyme is bound in muscle glycogen phosphorylase $(E C$ 2.4.I.I). Katunuma, Kominami \& Kominami (1971) have reported the presence of an enzyme that specifically inactivates PALPdependent apoenzymes. This activity appears during pyridoxine deficiency in tissues such as intestine and muscle, but not in more vital tissues such as liver, and these authors suggest that such a mechanism permits a shift of PALP from less vital tissues to more important ones when the supply of the coenzyme is limited. A similar mechanism may come into operation in riboflavin deficiency if the supply of PALP becomes limiting; (e) an increase in activity of some PALP enzymes such as transaminases has been reported in riboflavin deficiency (Chatterjee et al. 1966; Krishnaswamy, 1971). This may be due to stimulation of the adrenal cortex, as riboflavin 
deficiency does lead to hyperactivity of the adrenals initially, although they atrophy in terminal stages (Chatterjee \& Ghosh, 1970).

It is possible that the requirement for PALP is increased in riboflavin deficiency due to an increase in some PALP apoenzymes. This may lead to unequal distribution of the coenzyme and a bizarre biochemical profile, stimulating some PALP-dependent functions and depressing others without altering the over-all body pool of PALP. Similar alterations in PALP-dependent reactions are known to occur in rats and humans treated with contraceptive steroids (Aly, Donald \& Simpson, I97r; Brin, I97I), and in rats treated with cortisol (Lefauconnier, Portemer, Debilly, Ipakitchi \& Chatagner, I973).

The results of the human studies suggest that oral pathology that responds to either riboflavin or pyridoxine is not associated with changes in the circulating concentrations of PALP. The last two possibilities discussed above need to be investigated to reconcile the biochemical and the clinical observations made in the human study.

We are grateful to Dr C. Gopalan, Director, National Institute of Nutrition, for his keen interest and helpful suggestions. We thank Dr Kamala Krishnaswamy and Dr Krishnamachari for supplying the blood samples for the human studies.

\section{REFERENCES}

Anderson, B. B., Fulford-Jones, C. E., Child, J. A., Beard, M. E. J. \& Bateman, C. J. T. (1971). 7. clin. Invest. 5o, I90x.

Aly, H. E., Donald, E. A. \& Simpson, M. H. W. (197I). Am. F. clin. Nutr. 24, 297.

Bamji, M. S. (r969). Clinica chim. Acta 26, 263.

Bamji, M. S. (197I). Proc. Ist Asian Congr. Nutr. p. 142 [P. G. Tulpule and K. Jaya Rao, editors]. India.

Bamji, M. S. \& Sharada, D. (1972). F. Nutr. 102, 443.

Brin, M. (1971). Am. F. clin. Nutr. 24, 699.

Chatterjee, A. K. \& Ghosh, B. B. (1970). Endokrinologie 56, 218.

Chatterjee, A. K., Jamdar, S. C. \& Ghosh, B. B. (1966). Experientia 22, 794.

Iyengar, L. (1973). Lancet i, 680 .

Katunuma, N., Kominami, E. \& Kominami, S. (1971). Biochem. biophys. Res. Commun. 45, 70.

Krishnaswamy, K. (I97I). Int. Z. VitamForsch. 4I, 247.

Lefauconnier, J., Portemer, C., Debilly, G., Ipakitchi, M. \& Chatagner, F. (1973). Biochim. biophys. Acta 297, I35.

Mason, M. (1953). F. biol. Chem. 201, 5 r3.

Nakahara, I., Morino, Y., Morisue, T. \& Sakamoto, Y. (r96r). J. Biochem., Tokyo 49, 339.

Nakahara, I., Watanabe, Y., Morino, Y. \& Sakamoto, Y. (I96I). F. Biochem., Tokyo 49, 343.

Rose, D. P. \& McGinty, F. (1968). Clin. Sci. 35, r.

Sharada, D. \& Bamji, M. S. (I972). Int. Z. VitamForsch. 42, 43.

Storvick, C. A., Benson, E. M., Edwards, M. A. \& Woodring, M. J. (1965). Meth. biochem. Analysis 12,183 .

Strobeker, R. \& Henning, H. M. (1965). Vitamin Assay Tested Methods p. I44. Weinheim: Verlag Chemie GmbH.

Sundaresan, P. R. \& Coursin, D. B. (1970). Meth. Enzym. 18, 509.

Suzue, R. \& Tachibana, M. (1970). F. Vitam. 16, 164.

Wada, H. \& Snell, E. E. (1961). Y. biol. Chem. 236, 2089. 